\title{
Minorities and multicultural education at universities
}

\author{
JUDr. Alexandra HOCHMANOVÁ, Ph.D.
}

\begin{abstract}
The author addresses on a multidisciplinary platform and from the theoretical legal and philosophical legal perspective the issue of minorities and multicultural education at universities. Through its criticism she reveals the emptiness and confusion of the concepts of social sciences and humanitarian disciplines and brings to light the 'asset stripping' of the normative systems.

Multiculturalism in the context of a value-based university education is presented as relativism applied in the field of the social sciences with repercussions on social engineering and complete transformation of cultural and social values.

Her conclusions about value perception and interpretation of multidisciplinary concepts of multiculturalism unearth in the final analysis concurrent processes leading to ideologization of scholarly disciplines and in particular law, which ceases to be a value and becomes a means used by the power structures of the globalized world.
\end{abstract}

\section{Keywords}

multiculturalism, multicultural education, legal education, legal culture, minorities

Educational and instructive activities at universities and their scientific and research activities are currently confronted with a comprehensive understanding of the broad context of social development in the context of a global world. In today's life full of diversity, the growing importance of cultural pluralism, which is also the cause of ever-increasing migration, is realised. An expression of this fact is the emphasis placed on the concept of multiculturalism as a set of socio-scientific theories and concepts dealing with various aspects of these phenomena.

In an effort to prevent problems in cohabitation and negative social phenomena, a positive integration policy is pursued, mainly affecting minorities from countries with visa and residence restrictions. Its open nature has long sought to create the conditions for the inclusion and acceptance of these minorities in majority society. This is facilitated by multicultural education aiming to address a wide range of minority issues. The research on the various influences of cultural diversity includes the fields of anthropology, ethnology, social methods, intercultural psychology, social and developmental psychology, intercultural 
communication, international education, political science, protection of human rights and cultural relativism. ${ }^{1}$

Multicultural (intercultural) education is, in the broadest sense, an educational activity aimed at teaching understanding of people from different ethnic, peoples, racial and religious groups and preparing them for coexistence, respect and cooperation. The aim of multicultural education is, in particular, to shape the personality of individuals so that they can live in a multicultural society and contribute to the optimal coexistence of diverse groups of individuals. ${ }^{2}$

Multicultural education is pursued across the curriculum of primary and secondary schools that are part of compulsory education, as well as in out-of-school activities through educational events and promotional campaigns, including the application of political means. ${ }^{3}$ Foreign nationals' children attend schools compulsorily under Section 20 of the Education Act, and Decree No. 48/2005 Sb., Section 21(4). ${ }^{4}$

At the level of university education, viewed from the perspective of broader philosophical, sociological, economic, cultural, political and environmental questions, envisages a public discussion on social and ethical questions with regard to the development of a multicultural society. ${ }^{5}$ The key provisions of the University Act set this framework for the multicultural platform of university education in the Preamble to Section 1 of the Universities Act.

It is said that the universities, being the highest link in the education system, are supreme centres for education, independent cognition and creative activities, playing a central part in scientific, cultural, social and economic development by playing, inter alia, an active role in public discussions of social and ethical questions, in cultivation of cultural diversity and mutual understanding, shaping of a civil society, and preparation of young people for living in it. The following provisions highlight the role of universities in their contribution to development at the national and regional level and fostering of international and European cooperation. ${ }^{6}$

Multicultural education at universities is an open space for detailed legal regulation of providers of foreign university education in the territory of the Czech Republic, including

1 VALIŠOVÁ, Alena - KASÍKOVÁ, Hana (eds.): Pedagogika pro učitele [Pedagogy for teachers], Prague $2011,323$.

2 Ibidem, 322.

3 For example, as part of the Edison project foreign university students attend Czech schools and introduce Czech students to traditions and cultures of their countries of origin. Online: http://zpravy.idnes.cz/rozstrel-hynek-charousstiznost-na-skolu-hysterie-kvuli-cizincum-1d7-/domaci.aspx?c=A170324_144804_domaci_jkk (Downloaded 2 April 2017).

4 Citizens of the European Union thus have guaranteed access to education and school services under the same conditions as citizens of the Czech Republic. Foreign nationals who are not citizens of the European Union have access to primary, college and higher vocational education under the same conditions as citizens of the EU. (Act No. 561/2004 Sb., on Preschool, Primary, Secondary, Higher Vocational and other Education, and Decree No. 48/2005 Sb., on Primary Education and some requisites of compulsory school attendance.)

5 Act No. 111/1998 Sb., Universities Act, amending certain related laws (Universities Act), as last amended, Section 1.

6 Ibidem. 
state regulation of licensing of branches of foreign universities in Section 14 of the Universities Act. ${ }^{7}$ Engaging universities in a broad and wide-ranging debate on the issue of multicultural plurality is part of the key and comprehensive task that educational institutions perform in the scientific, cultural, social and economic development of society.

The philosophical and political view of multicultural education starts from multiculturalism and the concept of universality of human rights, and cultural relativism that treats cultures as equal and does not consider them according to the criteria 'better' and 'worse' or 'advanced' and 'primitive'. By contrast, the ethnocentric view evaluates other cultures from its own position based on comparison and assessment which are part of critical thinking. It states that in consequence of an imbalanced approach and domination of extreme positions of multiculturalism in multicultural education students can be indoctrinated by ethnic ideologies. ${ }^{8}$ This does not result in eradication of prejudices and negative dogmas will multiply nationalist teaching according to ethic criteria in a minority version. ${ }^{9}$

Opinions are voiced in academic literature that despite a comprehensively elaborated theoretical points of departure and long real-life experience of the effects of multicultural education, in particular long-ranging educational activities in Western Europe and North America, no real effect and real results have been demonstrated in practical life. ${ }^{10}$ On the contrary, one can hear increasingly teachers' voices saying that teaching of most social sciences is today a consequence of liberal education of victims of a schizophrenia: Under the pressure of political correctness teachers hardly express an opinion whereas, on the other side, students can claim anything and it is considered creative and inspiring.

The cult of liberal humanism in education may lead in its pronounced form to disruption of civic balance in politics and before the law. Its advocates proclaim one humanity and confuse human rights with universal ethics and political rights and duties. ${ }^{11}$ Political instruments prefer stances rejecting natural boundaries between people and cultures, external and internal, that support the autonomy of the family, school, community, associations and unions. All-embracing humanism of multicultural education is to teach people to love strangers more than one's own folk, humanity more than nation. ${ }^{12}$

With reference to political correctness, which should have been a label for respect, a liberal effort is spreading to 'liberate' humankind from culture, history, and religion, destroying

7 Ibidem, Section 93a-93k.

8 Criticism of multiculturalism is represented in the Czech milieu by staff of the Department of Antropology, University of Western Bohemia in Pilsen with a collection of studies 'Soudobé spory o multikulturalismus a politiku identit'. (HIRT, Tomáš - JAKOUBEK, Marek (eds.): Soudobé spory o multikulturalismus a politiku identit [Contemporary disputes over multiculturalism and identity policy], Pilsen 2005).

9 Ibidem, 53.

10 PRŮCHA, Jan: Multikulturní výchova [Multicultural education], Prague 2011, 15.

11 SARTORI, Giovanni: Pluralismus, multikulturalismus a pristěhovalci [Pluralism, multiculturalism and immigration], Prague 2011, 14-123.

12 Online: https://www.novinky.cz/komentare/420906-komentar-amok-americkych-liberalu-alexander-tomsky. html (Downloaded 17 November 2016). 
language, thinking, discipline, authority, competition, and all virtues. It refuses to differentiate between higher and lower, better and worse, noble and barbarian. It regards society as a sum of equal individuals, not an organism. ${ }^{13}$ It supresses the perception of people's individual value given by their spiritual dimension.

The demand for multicultural education, tolerance and non-discrimination comprises creation of equal opportunities by means of democratic processes and application of a non-selective community approach. In this context the view of multiculturalism or inter-culturalism separating it from pluralism is on the rise. ${ }^{14}$ The intention is being advocated in this sense that members of other cultures have a right to preserve their cultures unless doing so interferes with the free will of members of other cultures. ${ }^{15}$ Feedback from popular referendums and election results are beginning to show that democracy is beginning to diverge from radical manifestations of the ideology of liberalism. In cultivation of cultural diversity and mutual understanding at universities, and in particular preparation of university students for the creation of a civil society in teaching and philosophical faculties it will be necessary to take into account majority opinions of democratic society.

Multicultural education and the issue of minorities has been influenced at universities by the approach of the European Court of Human Rights together with ramifications for the continental type of legal culture in Europe. ${ }^{16}$ Value judgments of values in themselves in a value-based approach to education cultivate with their extreme teleological form the interpretations of an ideology that conceals under the cloak of political correctness distorted views of law, equality, freedom, and democracy.

Multicultural education supports the blurring of traditional conservative positions and patterns. Confusion of terms in the complex formation of cosmopolitan and multicultural views of reality leads to their emptying. ${ }^{17}$ This fact determines and modifies the perception

13 People are not equal in aristocratic virtues. Egalitarian deification of the individual without regard for natural civilisation, cultural and moral standard leads to decline. (Ibidem).

14 Critical views warning against numbers of immigrants include ideas of Giovanni Sartori, internationally recognised Italian expert and professor at Florence University and Columbia University, New York, who points to dangers of liberal policy concerning migration from Islamic countries. In an essay on multi-ethnic society he says: "The term 'pluralism' is popular today which does not mean it is correctly understood. It is the contrary. As proof of its misunderstanding I consider the notion that multiculturalism - a policy endorsing ethic and cultural differences - represents a continuation and deepening of pluralism... I say that the idea of a complementary pluralism and multiculturalism is wrong as these are two contradictory terms that negate one another." (SARTORI, 9).

15 BALVíN, Jaroslav: Pedagogika, andragogika a multikulturalita [Pedagogy, Andragogy and Multiculturalism], Prague 2012, 60.

16 See Judikatura - Databáze vybraných rozhodnutí Evropského soudu pro lidská práva [Database of selected decisions of the European Court of Human Rights], online: http://eslp.justice.cz/justice/judikatura_eslp.nsf/WebSpreadSearch (Downloaded 2 April 2017).

17 Key terms used in multicultural education include 'minority', 'ethnic group', 'ethnic consciousness', 'ethnicity', 'race', 'culture', 'cultural relativism', 'assimilation', 'integration'. In practice, ethnic group or ethic consciousness is identified with the category 'nationality' and ethic space with the category 'homeland'. "For multicultural education the existence of nations is a very problematic matter." (PRÜCHA, Multikulturní výchova, 23, 24 through 28). 
of needs of the late period of modernity, in which society lost its immunised character and is going through a value orientation crisis. ${ }^{18}$

Multicultural education is presented as a point of departure for a solution of the adverse demographic developments, stressing the overcoming the traditional function of the family and support for natality. For this reason legal relations are preferred that deal with new forms of coexistence upholding the participants' rights in marriage and in registered partnership. The emphasis is placed in the economic area on globalism and supranational interests veiled in the social here by a cloak of humanism common to all mankind. ${ }^{19}$

Understanding the key terms and concepts of multicultural education is not easy since the interdisciplinary terms in use and its very conception are not fixed and opinions of its purposefulness and functioning differ even abroad. ${ }^{20}$ The doctrines of social sciences develop the interdisciplinary character of multicultural education as an area of scientific research and are based mainly on pedagogical and psychological theory. In practical terms, it emphasizes the economic 'usefulness' of the impact of migration policy and the free movement of migrants, which offers solutions to problems of economic and demographic nature, to a lesser extent, notes the links of political, ethical and social contexts.

Multicultural education at all school levels including university education, above all in teaching colleges, helps to re-evaluate the task of traditional national states and all forms of patriotism and national identity. ${ }^{21}$ The value view of multicultural concepts of social phenomena or inter-culturalism as its complementary and more advanced form is presented as a solution to overcome the national horizon and to develop national traditions fully on the worldwide level. ${ }^{22}$

Emancipation (national) concept of history is merely pathetic and empty rhetoric. This is justified by the assertion that an increasing number of young people identify with modern means of communication and social media linked to manifestations of globalisation supported by global capital, supranational corporations and intergovernmental organisations. An ideological pressure is brought to bear to view the world through the prism of multiculturalism, going hand in hand with modern organisational forms of teaching and teaching methods at universities.

18 See MACINTYRE, Alasdair C.: Ztráta ctnosti: k morální krizi současnosti [After Virtue: A Study in Moral Theory], Prague 2004, 332, or HAN, Byung-Chul: Vyhořelá společnost [Burned society], Prague 2016.

19 Online: https://www.novinky.cz/komentare/431012-komentar-nic-uz-nebude-jak-bylo-jiri-pehe.html\#utm_source=search.seznam.cz\&utm_medium=hint\&utm_content=freshnews\&utm_term=pehe (Downloaded 3 March 2017).

20 PRŮCHA, Multikulturní výchova, 23.

21 Act No. 561/2004 Sb. employs the term 'national minority' whereas The Framework Educational Programme for Basic Education (2005) uses the terms 'minority ethnic group' and 'national group'.

22 "It is only when a representative of a minority can turn against an imaginary cultural majority its constitution does real integration begin. Only in the experience of that 'insult', in the felling of the gap severing the established connection between truth and majority opinion can cultures become equal and their members can meet in the space thus created to create on the basis of multiplicity of cultures a common culture of multiplicity" (DOKUPIL ŠKABRAHA, Martin: Národní kultura nezemře. V postmajoritní společnosti lze některé podněty našich tradic naplno rozvinout až na světoobčanské rovině, in: Lidové noviny, 18 February 2017, 15). 
In the loosening of the plurality of truths and confusion of values of late modernity multicultural education, in particular in faculties of education, calls on people to kneel before the historic mythology of other cultures and resign to one's own view. ${ }^{23} \mathrm{~A}$ social altruism is expected without a sense of responsibility for generation of an evolutionary chain in the system, and precisely from the perspective of the attitude to the culture of own community and its point of view.

Multicultural education is part of value education at universities whose importance has been growing in importance lately and is overestimated in a number of respects. In its overstressed conception it helps to cover the point of gravity of the substance of scientific disciplines with non-transparent wrappings and through values and principles the value judgment is substituted for traditional normative systems. Transformed into forms of ideology, demagogy, education, and efforts to teach people to think value education blurs the fragile boundary between various forms of this operation and may function as a mechanism for skilful manipulation with human consciousness. Like formerly religion with equality before God or communism with expropriation of property, a modern-day egalitarianism comes with adoration of human-rightist multiculturalism. This view negates with an antidiscrimination constant difference and diversity and calls into question own points of departure and directions. It views diverse cultures ethnocentrically and expects from the position of its stances mutual respect and cooperation between cultures. ${ }^{24}$

Multicultural education at universities does not contribute to the professional development of scholarly disciplines since the gamut of their effect is directed at standpoints of relativising nature and subjective character. It only sees some aspects of diversity and forgets that a pluralist conception of verities creates further stereotypes. Interdisciplinary character of multicultural education goes beyond the theoretical framework of conception of individual fields of study and ignores the application impact on the factual functioning of society. In this context a number of works state that multicultural education, even if it is ingenuously elaborated on the theoretical plane, failed in its effect and result on the practical level of life. ${ }^{25}$ Defining of values with a number of variables and few constants raises a number of questions of nationwide importance who problem is in the future more connected with un unforeseeable conclusion of a solution than the current dilemma of controversial claims and dogmas.

Understanding of multicultural education does not elucidate the current shift from ethic and national understanding of cultural diversity to diversity of socio-cultural groups and acceptance of the fact that one can be concurrently part of one or more cultures. University education cannot, despite newly emerging efforts to modify the interpretations of different

23 PINKAS, Jaroslav - HOŘENÍ, Karina: Dějepis je mnohem víc než data. Jsem na straně těch, kdo s prázdnýma rukama buší na dveře, in: Lidové noviny, 19 March 2016, 1 and 19, 24 and 25.

24 Optimistic views of multicultural education start from one's own seeing of reality from the angle of democratic values. It is expected that different cultures will respect the fundamental constitutional rights and obligations of all the citizens of a society and no community will radicalise itself so much that it will stand against others and act against the interests of other cultures.

25 PRŮCHA, Multikulturní výchova, 148-157. 
conceptions of multiculturalism and inter-culturalism and the creation of its terminology, ${ }^{26}$ create the conditions for such education and educational efforts in university institutions. Through development of reflection of students' individual identity as part of tuition of academic disciples at universities multicultural education in social sciences and the humanities may cause a certain ideologization of scientific disciplines. Such an approach represents indoctrination of students and allows a misuse of the value system in education and expedient relativisation of scientific findings in the humanities. In this sense it is fair to ask what the aim is and the means for this view of education. If education is to be the aim as an intrinsic value contributing to learning in society, this means its mediation should not be expected to result in another value unless the intention is precisely expedient transformation of learning by its value judgment. ${ }^{27}$

Multicultural education at universities, if it predominates in the practice of pedagogic, philosophical, sociological, political science and legal disciplines, deploys instruments of social engineering and a fundamental transformation of cultural and social values. ${ }^{28}$ On the theoretical plane it distorts objective conception of scientific work and teaching of academic disciplines starting from a relativising approach to their understanding. At regional and national level it reappraises the importance of spiritual wealth of cultural diversity and in the context of European and international reach it empties the real values of democracy and humanism. In consequence it does not develop learning in society, the Holy Grail of the diligent and the capable handed down to us by previous generations.

\section{References}

DOKUPIL ŠKABRAHA, Martin: Národní kultura nezemře. V postmajoritní společnosti lze některé podněty našich tradic naplno rozvinout až na světoobčanské rovině, in: Lidové noviny, 18 February 2017, 15.

PINKAS, Jaroslav - HOŘENÍ, Karina: Dějepis je mnohem víc než data. Jsem na straně těch, kdo s prázdnýma rukama buší na dveře, in: Lidové noviny, 19 March 2016, 1 and 19, 24 and 25 .

26 As for key terms and definitions cf. e.g. BALVÍN, 48-52; Velký sociologický slovník [The Great Sociological Dictionary], Prague 1996, 548-549; PRŮCHA, Multikulturní výchova, 20-40 and PRŮCHA, Jan (ed.): Pedagogická encyklopedie [Pedagogical Encyclopedia], Prague 2009.

27 The value-based approach in law triggered in the process of judicialization the destruction of the continental legal culture. By emptying the normative systems through value-based education and value-based interpretation of law, the theory of legal science was made to face the reality of having to defend its own doctrine. The law, which is in itself a value with a value concept, has become a mere medium for the mediation of other values. In this sense, the value of the law has been emptied, the value it has in itself, and the value concept has become a mere means. With this 'normative tunnel' the law as a value in itself is replaced by the values of other normative systems while preserving the same formal terminology. In short: "Through looking for decency in the law, we have forfeited the 'decent law'. In this sense, the law can be understood in two ways: Either statically as a value, and in this case the value-based interpretation is an absurd duplication, for the value is interpreted in a value-based way. Or, the law can be perceived dynamically as a purpose and a means of getting to another value teleologically."

28 Let us add with a degree of exaggeration that the value-based approach is not going to be adopted by doctors and the general validity of the Hippocratic Oath is not going to be challenged in medical schools. 
Act No. 111/1998 Sb., Universities Act, amending certain related laws (Universities Act), as last amended, Section 1, Section 93a-93k.

Act No. 561/2004 Sb., on Preschool, Primary, Secondary, Higher Vocational and other Education.

BALVÍN, Jaroslav: Pedagogika, andragogika a multikulturalita [Pedagogy, Andragogy and Multiculturalism], Prague 2012.

Decree No. 48/2005 Sb., on Primary Education and some requisites of compulsory school attendance.

HAN, Byung-Chul: Vyhořelá společnost [Burned society], Prague 2016.

HIRT, Tomáš - JAKOUBEK, Marek (eds.): Soudobé spory o multikulturalismus a politiku identit [Contemporary disputes over multiculturalism and identity policy], Pilsen 2005.

Judikatura - Databáze vybraných rozhodnutí Evropského soudu pro lidská práva [Database of selected decisions of the European Court of Human Rights], online: http://eslp.justice. cz/justice/judikatura_eslp.nsf/WebSpreadSearch (Downloaded 2 April 2017).

KOMENTÁŘ: Amok amerických liberálů - Alexander Tomský, online: https://www.novinky. cz/komentare/420906-komentar-amok-americkych-liberalu-alexander-tomsky.html (Downloaded 17 November 2016).

KOMENTÁŘ: Nic už nebude, jak bylo - Jiří Pehe, online: https://www.novinky.cz/ komentare/431012-komentar-nic-uz-nebude-jak-bylo-jiri-pehe.html\#utm_source=search. seznam.cz\&utm_medium=hint\&utm_content=freshnews\&utm_term=pehe (Downloaded 3 March 2017).

MACINTYRE, Alasdair C.: Ztráta ctnosti: k morální krizi současnosti [After Virtue: A Study in Moral Theory], Prague 2004.

Multikulturní výchova ve škole je zlo, řekl v Rozstřelu stěžující si rodič, online: http://zpravy. idnes.cz/rozstrel-hynek-charous-stiznost-na-skolu-hysterie-kvuli-cizincum-1d7-/domaci. aspx?c=A170324_144804_domaci_jkk (Downloaded 2 April 2017).

PRŮCHA, Jan (ed.): Pedagogická encyklopedie [Pedagogical Encyclopedia], Prague 2009. PRŮCHA, Jan: Multikulturní výchova [Multicultural education], Prague 2011.

SARTORI, Giovanni: Pluralismus, multikulturalismus a přistěhovalci [Pluralism, multiculturalism and immigration], Prague 2011.

VALIŠOVÁ, Alena - KASÍKOVÁ, Hana (eds.): Pedagogika pro učitele [Pedagogy for teachers], Prague 2011.

Velký sociologický slovník [The Great Sociological Dictionary], Prague 1996.

\section{Author}

JUDr. Alexandra Hochmanová, Ph.D.

Právnická fakulta, Univerzita Karlova

Faculty of Law, Charles University

nám. Curieových 901/7, 11640 Praha 1, Czech Republic

hochmano@prf.cuni.cz 